\title{
NOTES AND NEW TECHNIQUES
}

\section{(1) \\ GEM-QUALITY HAÜYNE FROM THE
EIFEL DISTRICT, GERMANY}

By Lore Kiefert and H. A. Hänni

\begin{abstract}
Haüyne is a rare mineral and an extremely rare gemstone. Recently, the authors studied a large number of faceted haüynes from the Eifel district of Germany. The R.I. and S.G. data were consistent with those reported in the literature, and the samples' identity was confirmed by Raman spectrometry, with the key maxima at 543 and $988 \mathrm{~cm}^{-1}$. EDXRF analyses revealed potassium and iron, as well as the major and minor elements expected in haüyne. Although mineral inclusions were uncommon, apatite and augite were identified, and negative crystals (often surrounded by healed fractures) were seen in approximately one-third of the stones. Short needles and fine, dust-like particles were present in about half the samples. Paraffin wax was identified in some open fissures.
\end{abstract}

In the summer of 1999, the authors were surprised to receive 100 faceted haüynes (pronounced "hoween") for analysis. The client who submitted these stones subsequently fashioned most of them into a brooch set with diamonds and a pink sapphire (figure 1). This butterfly brooch sold at the Sotheby's November 1999 Geneva auction for 45,000 SFr (approximately US\$30,000).

In spite of its attractive color, however, haüyne is rarely seen in jewelry. Not only is the mineral

ABOUT THE AUTHORS

Dr. Kiefert (gemlab@ssef.ch) is a research scientist and assistant director of the SSEF Swiss Gemmological Institute, Basel, Switzerland. Dr. Hänni (H-A.Haenni@unibas.ch) is director of SSEF and professor of gemology at Basel University, Switzerland.

Please see acknowledgments at end of article.

Gems \& Gemology, Vol. 36, No. 3, pp. 246-253

(C) 2000 Gemological Institute of America itself rare, but it also has a relatively low hardness (5.5-6 on Mohs scale).

Transparent haüyne primarily occurs as small crystals (see also Mertens, 1984) of an unusual bright "apatite" to "sapphire" blue color. Mineralogically, it is a feldspathoid that belongs in the sodalite group (which also includes sodalite, lazurite, and nosean), and is often one of the components of lapis lazuli. The chemical formula for haüyne is ideally $(\mathrm{Na}, \mathrm{Ca})_{4-8} \mathrm{Al}_{6} \mathrm{Si}_{6}(\mathrm{O}, \mathrm{S})_{24}\left(\mathrm{SO}_{4}, \mathrm{Cl}\right)_{1-2}$ (Mandarino, 1999). The crystal system for this silicate is cubic, the crystal class is $\overline{4} 3 \mathrm{~m}$. Cleavage planes are distinct in the $\{110\}$ direction, and twinning is common along $\{111\}$. Haüyne has been reported as white to gray, green, yellow, and red (Arem, 1987), but only the blue color has been noted thus far as faceted material.

\section{GEOLOGY AND OCCURRENCE}

Haüyne is found in association with alkaline volcanic rocks (mainly phonolites, which are composed of alkali feldspar, mafic minerals, and felds- 


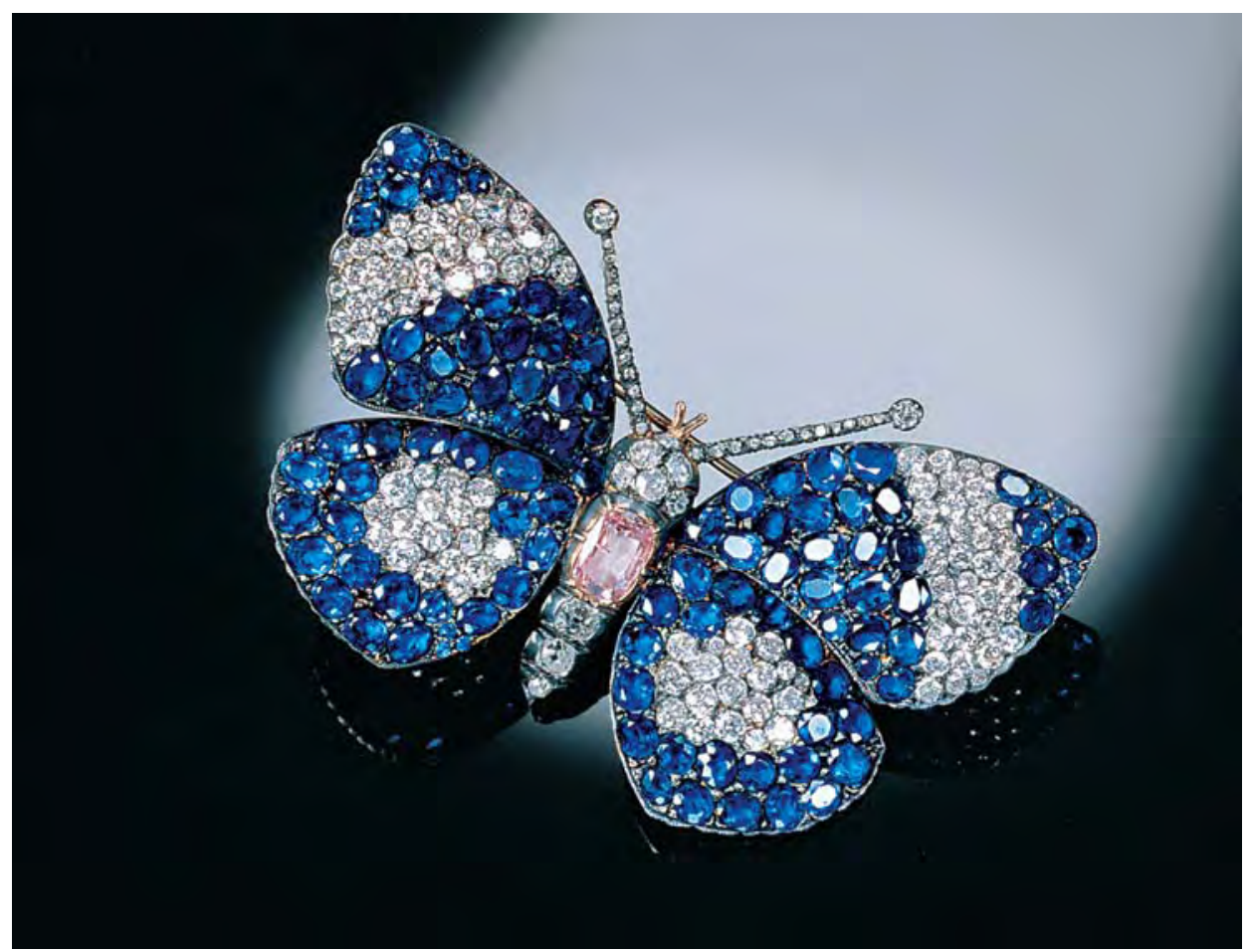

Figure 1. The authors had an opportunity to examine all of the haüynes before they were set in this attractive brooch with diamonds and a pink sapphire. The haüynes range from 0.095 to $0.173 \mathrm{ct}$. Photo courtesy of Della Valle.

pathoids; figure 2). It has been reported from many countries, including the U.S., Canada, France, Italy, Spain (Tenerife), Morocco, and Germany (Arem, 1987). In Germany, it occurs in relative abundance near Laacher See in the Eifel Mountains as gemquality crystals of an unusual blue color and transparency. Gem-quality material has not been reported from other sources (Fischer and Bürger, 1976; Arem, 1987).

In the Eifel Mountains, haüyne formed in a magma chamber approximately $2-4 \mathrm{~km}$ below the surface, together with a suite of minerals including sanidine, nosean, nepheline, leucite, plagioclase, amphibole, augite, magnetite, titanite, phlogopite, apatite, and olivine (Matthes, 1983; Wörner and Schmincke, 1984). This phonolitic magma was volatile-rich and chemically zoned, with a strong decrease in sulfur during progressive magmatic differentiation, which is interpreted to be partially caused by crystallization of haüyne (Harms and Schmincke, 2000). This magma erupted approximately 12,900 years ago, and the resulting volcanic rocks were deposited in three zoned layers. The bottom layer, which corresponds to the top of the magma chamber, is relatively crystal-poor and consists of a nearly aphyric, highly differentiated phonolite. The top layer, which transported the contents of the bottom of the magma chamber with crystal enrichment, consists of a relatively crystalrich mafic phonolite. Haüyne is found throughout all three layers (Schmincke, 2000; Harms and Schmincke, 2000).

We know of no attempts to mine haüyne commercially. Most of the crystals are found by amateur collectors (see, e.g., Linde, 1998). In the Eifel district,

Figure 2. At Laacher See, haüyne is found in a phonolitic pumice. This crystal measures 1.5 $\mathrm{mm}$ in longest dimension. Photo by Jean-Pierre Chalain.

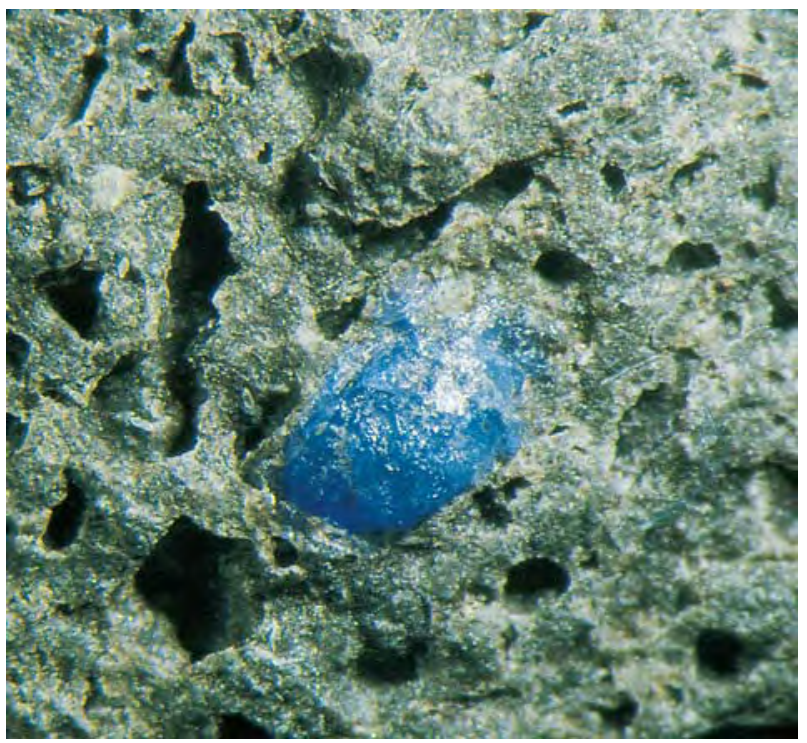




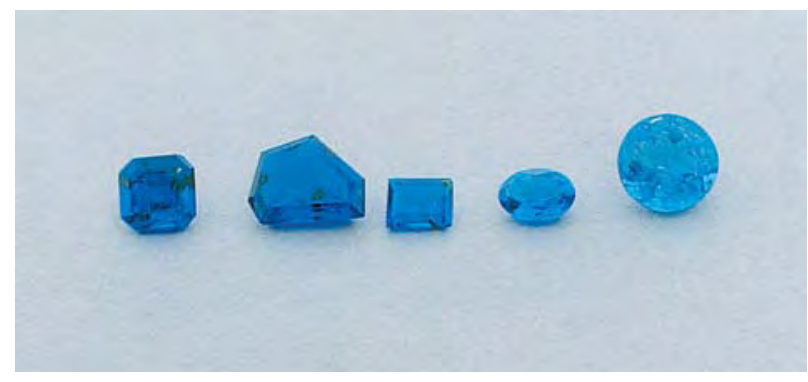

Figure 4. The haüyne samples examined ranged from a deep "sapphire" blue to a light "apatite" blue. These faceted stones weigh 0.2-0.8 ct. Photo by Lore Kiefert.

inclusions in several stones, with a Renishaw Raman System 1000 spectrometer equipped with a CCD Peltier detector and an argon ion laser (514 $\mathrm{nm}$ ) with a power of $25 \mathrm{~mW}$.

\section{RESULTS AND DISCUSSION}

The properties determined for these samples are summarized in table 1 and discussed below.

Physical Properties. The samples ranged from a light blue similar to that of Paraíba tourmaline or apatite, to a dark blue similar to that described for fine Kashmir sapphire (figure 4). Most of the samples, however, were an evenly distributed medium blue (see, e.g., figure 3 and the third and fourth stones from the left in figure 4). We did not observe color zoning in any of our samples.

The samples were very consistent in specific gravity (2.46-2.48), which corresponds to the range of 2.40-2.50 reported in the literature (Arem, 1987; Deer et al., 1992). Refractive index results, between 1.498 and 1.507 , also were consistent with the range cited in the literature (1.490-1.508; Bank, 1977, 1978-1979; Arem, 1987; Deer et al., 1992).

Approximately one-third of the 100 samples submitted to our laboratory (and a smaller proportion of the other samples) showed orange fluorescence to long-wave UV radiation; the remaining samples were inert. When fluorescence is observed, it is considered characteristic of haüyne from the Eifel district (Webster, 1994). The inconsistency in fluorescence reaction that we observed was also mentioned by Bank (1977). Most of the haüynes showed a very weak reddish fluorescence to short-wave UV.

Microscopic Properties. In approximately half of the samples, we observed short needles and fine dust-like particles arranged in lines, similar to rutile needles or partially dissolved rutile in sapphires (figure 5).

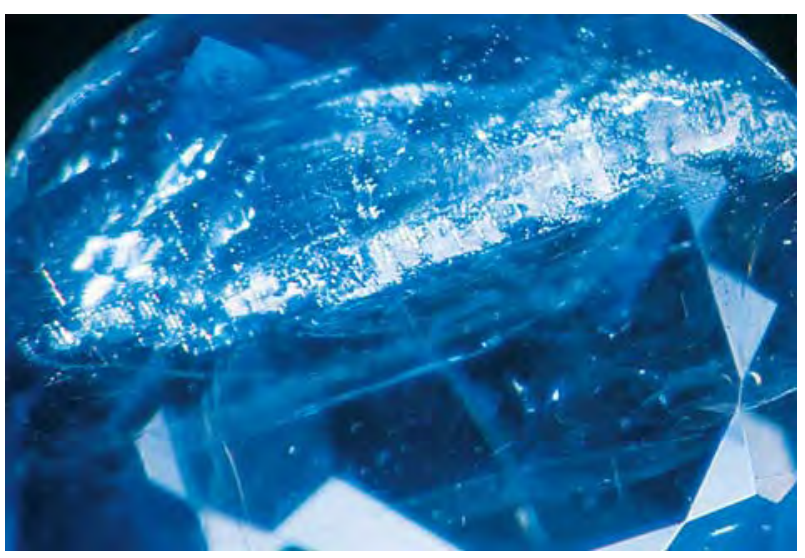

Figure 5. Short needle-like inclusions and fine dust-like particles were observed in about half the haüynes examined. The needles were generally oriented parallel to growth planes. Photomicrograph by H. A. Hänni; magnified 30x.

Elongate, transparent, prismatic crystals (figure 6), identified as apatite by Raman microspectrometry, were seen in two samples. In contrast to our findings, Wörner and Schmincke (1984) stated that apatite never occurs in haüyne from the Eifel district. Another mineral, which was exposed at the surface of one of the samples shown in figure 4, was identified as augite, which is also a common xenocryst in the Eifel district phonolite (Wörner and Schmincke, 1984). A dark opaque hexagonal crystal exposed at

Figure 6. Elongate prismatic crystals, identified as apatite by Raman analysis, were seen in two of the haüyne samples. Note also the piece of host rock evident on the surface of this sample, shown here at the upper left. Photomicrograph by H. A. Hänni; magnified 30x.

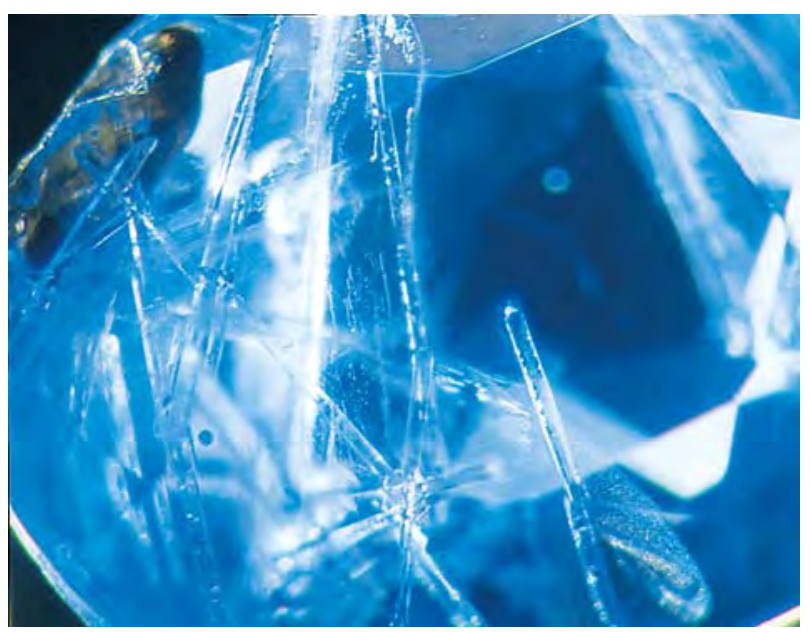




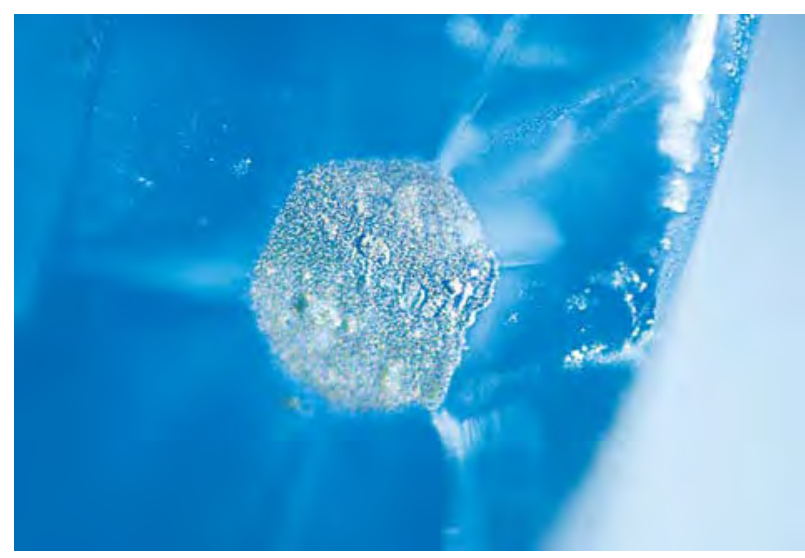

Figure 7. This hexagonal opaque crystal exposed at the surface of a polished haüyne was not identifiable with Raman analysis, possibly because it was metallic or too decomposed. Photomicrograph by H. A. Hänni; magnified 50×.

the surface of another stone could not be identified (figure 7). This inclusion may be metallic or too decomposed to give a useful Raman signal.

Negative crystals were observed in a third of the stones; some were well formed (figure 8), and some were rounded with a frosted surface (figure 9). They were frequently surrounded by healing fissures that resembled those seen around negative crystals in sapphires from Sri Lanka. In some cases, however, the partially healed fissures had an appearance similar to that of glass fillings in rubies (figure 10). Glass inclusions outlining growth zones in haüyne from the Eifel district were described by Harms and

Figure 9. This rounded negative crystal has a frosted surface and, like the smaller negative crystal on the lower right, a rosette-like healing fissure. Photomicrograph by H. A. Hänni; magnified $40 \times$.

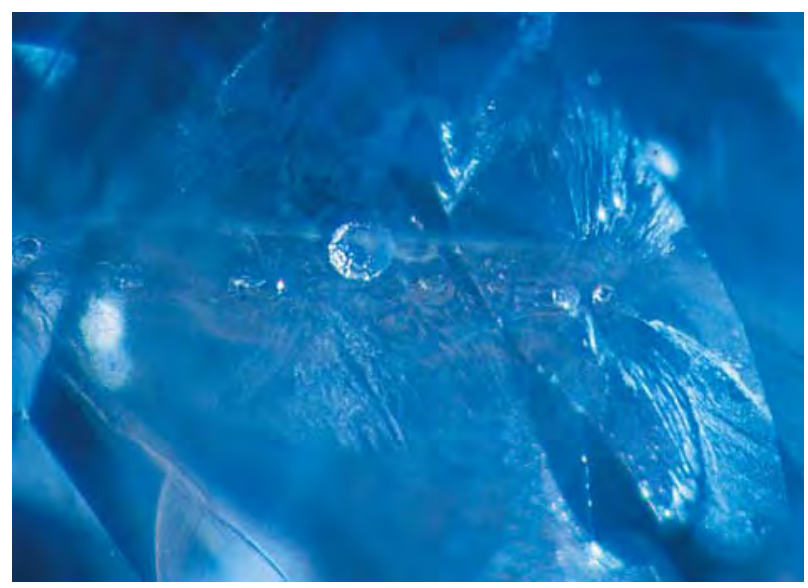

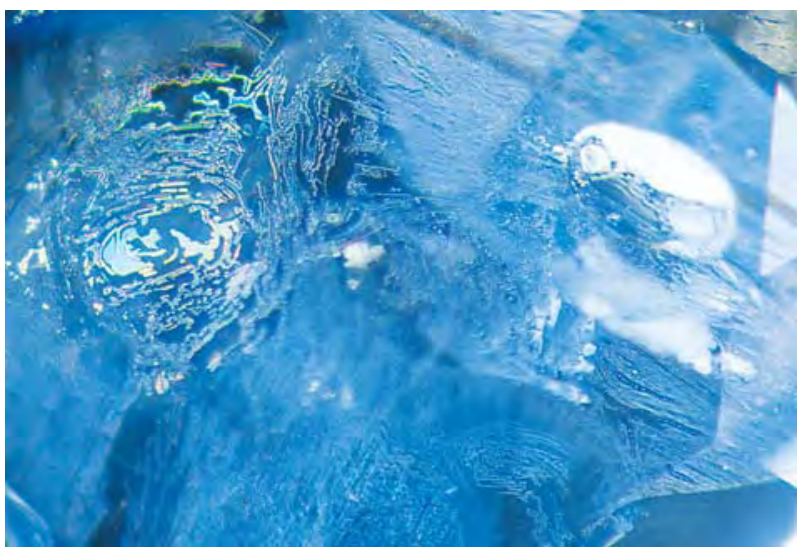

Figure 8. Commonly seen in the haüynes examined were well-formed negative crystals with rosette-like healing fissures (right, within the bright spot) or partially healed fissures with interference colors and a worm-like "fingerprint" structure (on the left). Photomicrograph by H. A. Hänni; magnified $40 \times$.

Schmincke (2000). Five of the samples examined contained remnants of the host rock (see, e.g., figure 6). Where the rough surface of the original crystal face was still visible, corrosion was evident.

Fissures filled with an oily to waxy substance were common in many of the 100 haüynes that were originally submitted to the laboratory for identification. This substance was identified as paraffin wax by FTIR and Raman analyses (see below). Because haüyne has a low refractive index, which is close to that of paraffin wax or oil, the filled frac-

Figure 10. In a number of the haüynes, the partially healed fissures resembled the glass fillings seen in some rubies. Photomicrograph by H. A. Hänni; magnified $30 \leftrightarrow$.

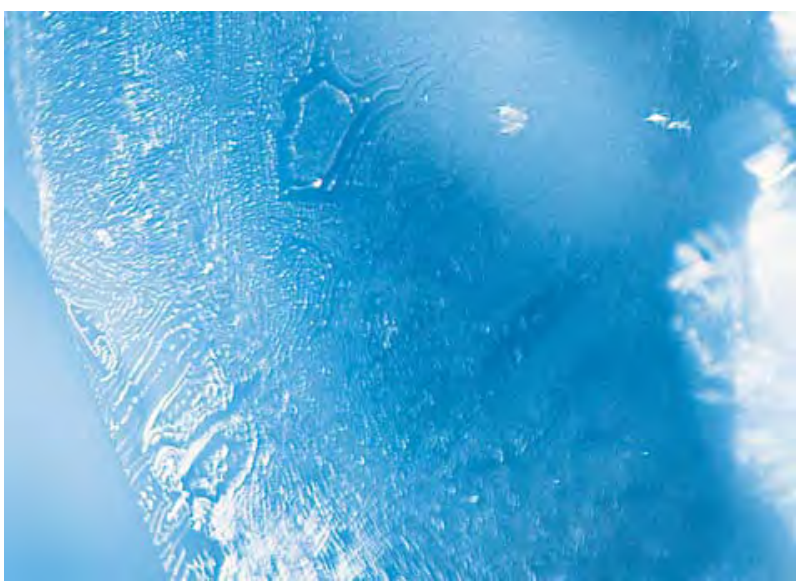


tures sometimes showed orange to pinkish flashes; these resembled the orange flashes observed in emeralds with resin-filled fractures (Kiefert et al., 1999; Johnson et al., 1999).

Spectral Features. UV-Vis spectrometry showed a major absorption band centered at approximately $600 \mathrm{~nm}$, maximum transmission at $476 \mathrm{~nm}$ (figure 11), a small absorption band centered at $380 \mathrm{~nm}$, and an absorption edge at $300 \mathrm{~nm}$ in the three stones tested. This is in agreement with the absorption spectrum reported for haüyne by Henn and Bank (1990). Note in figure 11 that the absorption band at $600 \mathrm{~nm}$ increases in intensity with increasing depth of color, while the other spectroscopic features remain the same.

An absorption band at $600 \mathrm{~nm}$, measured with electron paramagnetic resonance (EPR) spectroscopy, also has been described for sodalite and lazurite. This feature was ascribed to a color center associated with $\mathrm{S}_{3}^{-}$(Marfunin, 1979), which has been attributed to radiation damage (Vassilikou-Dova and Lehmann, 1990) and may be responsible for the blue color. Henn and Bank (1990) relate the orange fluorescence of this mineral group to the presence of $\mathrm{S}_{2}^{-}$, which causes the $380 \mathrm{~nm}$ absorption band. Note that only a weak, broad absorption band in the yellow region is visible with a handheld type of spectroscope.

The FTIR spectra in the region between 4000 and $2400 \mathrm{~cm}^{-1}$ of two stones in which magnification had revealed evidence of a waxy filler showed two major groups of peaks (figure 12): One is typical for haüyne and lies between 3000 and $3800 \mathrm{~cm}^{-1}$ (comparison with a "clean" sample); the other group of peaks (between 2840 and $2960 \mathrm{~cm}^{-1}$ ) is characteristic of paraffin wax. This latter group is attributable to the artificial filling of fissures with wax.

Chemical Properties. As noted above, the ideal chemical formula of haüyne is $(\mathrm{Na}, \mathrm{Ca})_{4-8} \mathrm{Al}_{6} \mathrm{Si}_{6}$ $(\mathrm{O}, \mathrm{S})_{24}\left(\mathrm{SO}_{4}, \mathrm{Cl}\right)_{1-2}$. Qualitative EDXRF chemical analysis of four stones showed, besides the detectable elements given in this formula (i.e., calcium, silicon, aluminum, and sulfur), small but significant amounts of potassium $(\mathrm{K})$ and iron $(\mathrm{Fe})$, as illustrated in figure 13.

According to Wörner and Schmincke (1984), it is difficult to perform microprobe analysis of haüyne because of the large sodium content, the decomposition of the haüyne under the electron beam, and the problem in assigning $\mathrm{SO}_{3}$ (as analyzed) to $\mathrm{SO}_{3}$ and $\mathrm{S}$. Therefore, those authors considered their microprobe

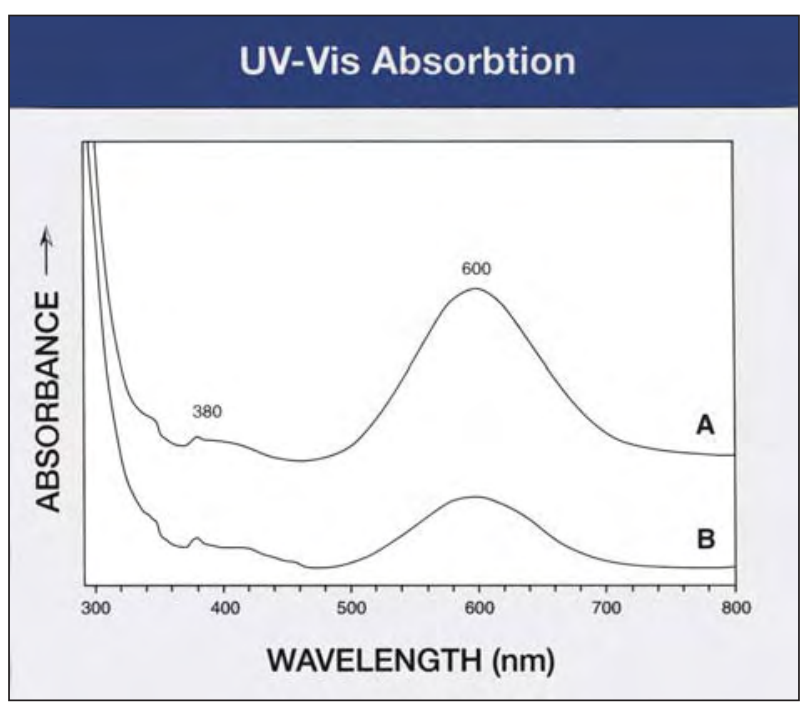

Figure 11. Note the characteristic absorption bands at 380 and $600 \mathrm{~nm}$ - and the transmission maximum at $476 \mathrm{~nm}$-in these UV-Vis absorption spectra of a medium blue (A) and a light blue (B) haüyne.

analyses of seven samples to be qualitative at best. The elements measured by our qualitative EDXRF analysis (including the significant amounts of $\mathrm{K}$ and $\mathrm{Fe}$ ) are consistent with the chemical data provided by these and other researchers for haüyne from Laacher See and from Italy (see also Deer et al., 1963; Xu and Veblen, 1995; Sapozhnikov et al., 1997).

Figure 12. Shown here are the FTIR spectra measured between 4000 and $2400 \mathrm{~cm}^{-1}$ of $(A)$ haüyne, (B) wax-treated haüyne, and $(C)$ paraffin wax. The peaks at 3697 and $3593 \mathrm{~cm}^{-1}$ are characteristic for haüyne.

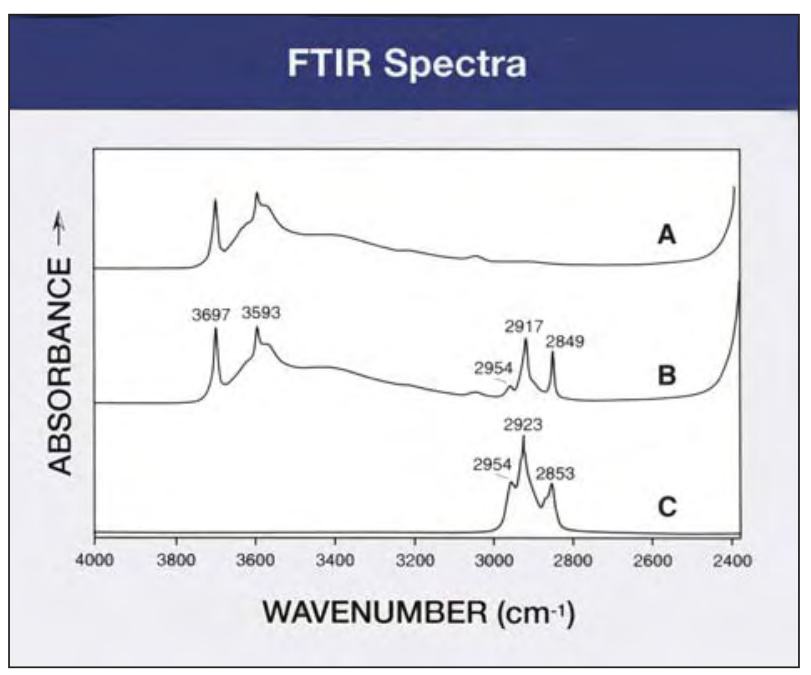




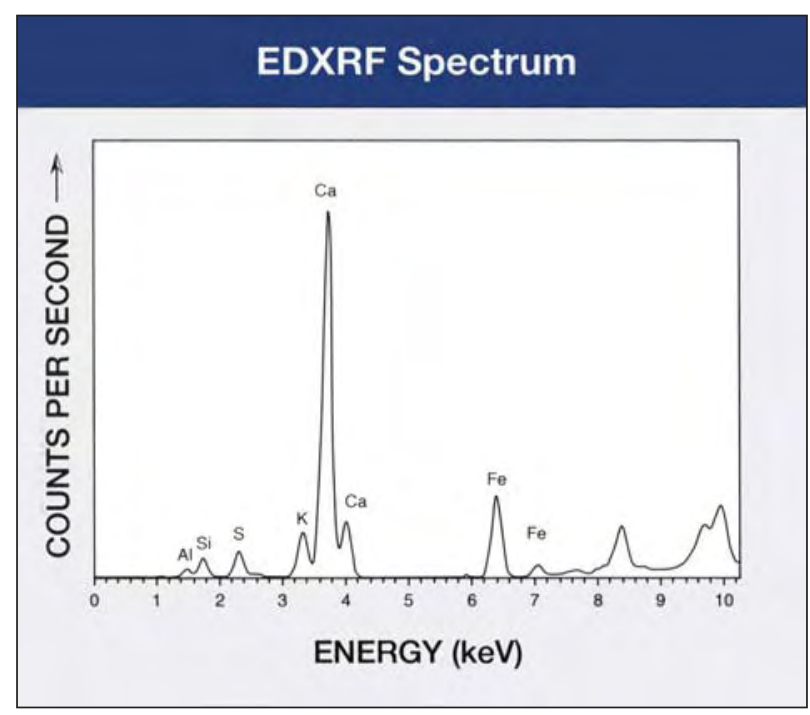

Figure 13. In addition to calcium, silicon, aluminum, and sulfur, EDXRF analyses of the haüyne samples revealed significant potassium and iron. The features above $8 \mathrm{keV}$ are instrumental artifacts related to the tungsten anode.

Raman Spectrometry. Raman analysis was performed on the haüyne itself and on all inclusions that were large enough to analyze. The Raman spectra of the four haüyne samples tested (see, e.g., figure 14) are in agreement with the results given by Maestrati (1989), but they differ significantly

Figure 14. The upper Raman spectrum is of paraffin wax found on the surface of a faceted haüyne, whereas the lower spectrum is of a haüyne reference sample.

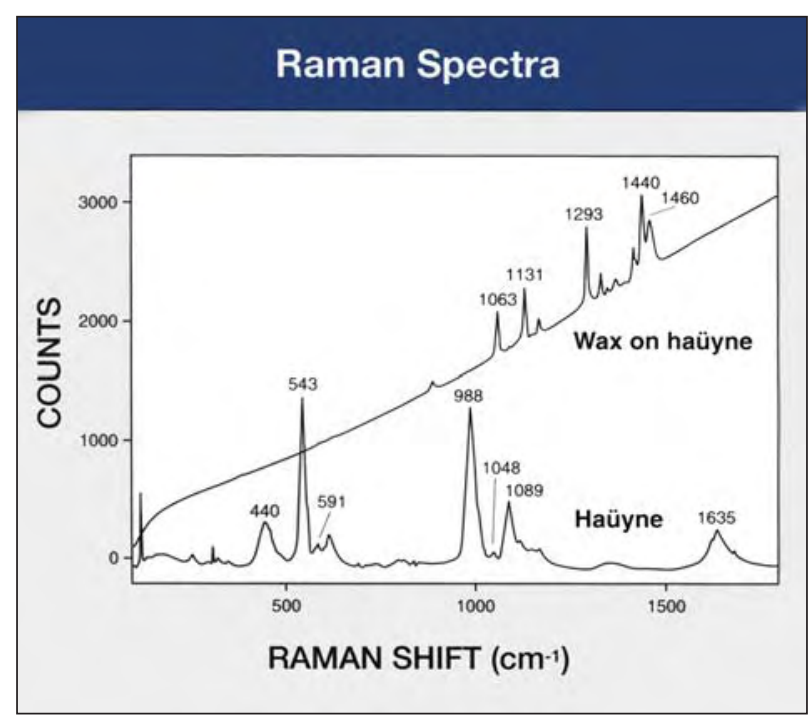

from those provided in the Renishaw Raman database.

Raman analysis identified both apatite and augite as inclusions in some of the samples. In addition, in one of the several samples that revealed fissure fillings with magnification, the filler was exposed on the surface of the stone, so we were able to get a particularly good Raman signal. The pattern matched that of paraffin wax (figure 14), which confirmed the results recorded with the FTIR spectrometer (again, see figure 12).

Separation from Possible Imitations. The bright blue color of haüyne might be duplicated by cobalt glass, blue cubic zirconia, or cobalt spinel. Lazurite and blue apatite also may resemble haüyne. Careful determination of the optic character (haüyne is cubic), R.I., S.G., and absorption spectrum will, however, enable a firm identification of haüyne. This mineral is clearly distinguishable from other minerals of the sodalite group by its Raman spectrum.

\section{CONCLUSIONS}

Although usually considered a collector's stone because of its rarity, haüyne may be found in expensive jewelry, as was the case with several of the stones tested for this article (again, see figure 1). The use of haüyne in a brooch is appropriate given its low hardness.

The geology and petrology of the deposit at Laacher See (Eifel district) in Germany have been well studied. It is interesting to note that similar volcanic deposits containing haüyne are rare, and we know of no other deposits of the blue gem-quality material. Although the German source has been productive for a long time-haüyne was first described from Germany in 1807 (Clark, 1993)—an accumulation of 100 faceted stones is surprising due to the relative scarcity of the material.

Acknowledgments: The authors thank P. Giese for taking FTIR, EDXRF, and UV-Vis spectra; Dr. M. Krzemnicki and J.-P. Chalain for their critical discussions; the company Della Valle of Geneva for supplying the original samples and the photo of the butterfly brooch; and Dr. J. Arnoth and Dr. K. Schmetzer for helping locate mineralogical literature about haüyne from the Eifel district. The companies Gebrüder Bank and W. Constantin Wild, both of Idar-Oberstein, Germany, kindly supplied a large number of additional samples. 


\section{REFERENCES}

Arem J.E. (1987) Color Encyclopedia of Gemstones, 2nd ed. Van Nostrand Reinhold, New York, 248 pp.

Bank H. (1977) Durchsichtiger, schleifwürdiger Hauyn aus der Eifel. Zeitschrift der Deutschen Gemmologischen Gesellschaft, Vol. 26, No. 4, p. 207.

Bank H. (1978-1979) Gemological notes: Blue gem haüyne. Gems (4) Gemology, Vol. 16, No. 4, p. 123

Clark A.M. (1993) Hey's Mineral Index, 3rd ed. Natural History Museum Publications, Chapman \& Hall, London.

Deer W.A., Howie R.A., Zussman J. (1963) Rock-Forming Minerals, Vol. 4: Framework Silicates. Longman, London, 435 pp.

Deer W.A., Howie R.A., Zussman J. (1992) An Introduction to the Rock-Forming Minerals, 2nd ed. Longman Scientific \& Technical, Essex, England, 696 pp.

Fisher K., Bürger H. (1976) Hauyn. Lapis, Vol. 1, No. 2, pp. 30-32.

Harms E., Schmincke H.-U. (2000) Volatile composition of the phonolitic Laacher See magma (12,900 yr BP): Implications for syn-eruptive degassing of $\mathrm{S}, \mathrm{F}, \mathrm{Cl}$ and $\mathrm{H}_{2} \mathrm{O}$. Contributions to Mineralogy and Petrology, Vol. 138, pp. 84-98.

Henn U., Bank H. (1990) Uber die Farbe der Sodalith-Minerale: Sodalith, Lasurit (Lapis lazuli) und Hauyn. Zeitschrift der Deutschen Gemmologischen Gesellschaft, Vol. 39, No. 2/3, pp. 159-163.

Johnson M.L., Elen S., Muhlmeister S. (1999) On the identification of various emerald filling substances. Gems \&) Gemology, Vol. 35, No. 2, pp. 82-107.

Kiefert L., Hänni H.A., Chalain J.P., Weber W. (1999) Identification of filler substances in emeralds by infrared and Raman spectroscopy. Journal of Gemmology, Vol. 26, No. 8, pp. 501-520.

Linde C. (1998) Hauyn-Kristalle von Teneriffa. Lapis, Vol. 23, No. 1, p. 22.
Maestrati R. (1989) Contribution à l'édification du catalogue Raman des gemmes. Unpublished diploma thesis, Diplôme d'Université de Gemmologie, Université de Nantes, France.

Mandarino J.A. (1999) Fleischer's Glossary of Mineral Species 1999. The Mineralogical Record Inc., Tucson, AZ.

Marfunin A.S. (1979) Spectroscopy, Luminescence and Radiation Centers in Minerals. Springer-Verlag, Berlin, p. 282.

Matthes S. (1983) Mineralogie. Eine Einführung in die spezielle Mineralogie, Petrologie und Lagerstättenkunde. SpringerVerlag, Berlin, p. 183.

Mertens R. (1984) Hauyn, ein seltener Edelstein. Zeitschrift der Deutschen Gemmologischen Gesellschaft, Vol. 33, No. 1/2, pp. 65-67.

Sapozhnikov A.N., Ivanov V.G., Piskunova L.F., Vasil'ev E.K. (1997) X-ray powder diffraction data of hauyne with incommensurate modulated structure from volcanic rocks of Laacher Lake, Germany. Powder Diffraction, Vol. 12, No. 1, pp. 3-6.

Schmincke H.-U. (2000) Vulkanismus. Wissenschaftliche Buchgesellschaft, Darmstadt, Germany, 264 pp.

Vassilikou-Dova A.B., Lehmann G. (1990) Paramagnetic defects in the mineral haüyne. Crystal Research and Technology, Vol. 25, No. 5, pp. 525-529.

Webster R. (1994) Gems, Their Sources, Descriptions and Identification, 5th ed. Rev. by P. G. Read, ButterworthHeinemann Ltd., Oxford, England, p. 342.

Wörner G., Schmincke H.-U. (1984) Mineralogical and chemical zonation of the Laacher See tephra sequence (East Eifel, W. Germany). Journal of Petrology, Vol. 25, Part 4, pp. 805-835.

Xu H., Veblen D.R. (1995) Transmission electron microscopy study of anisotropic and isotropic haüyne. American Mineralogist, Vol. 80, No. 1/2, pp. 87-93.
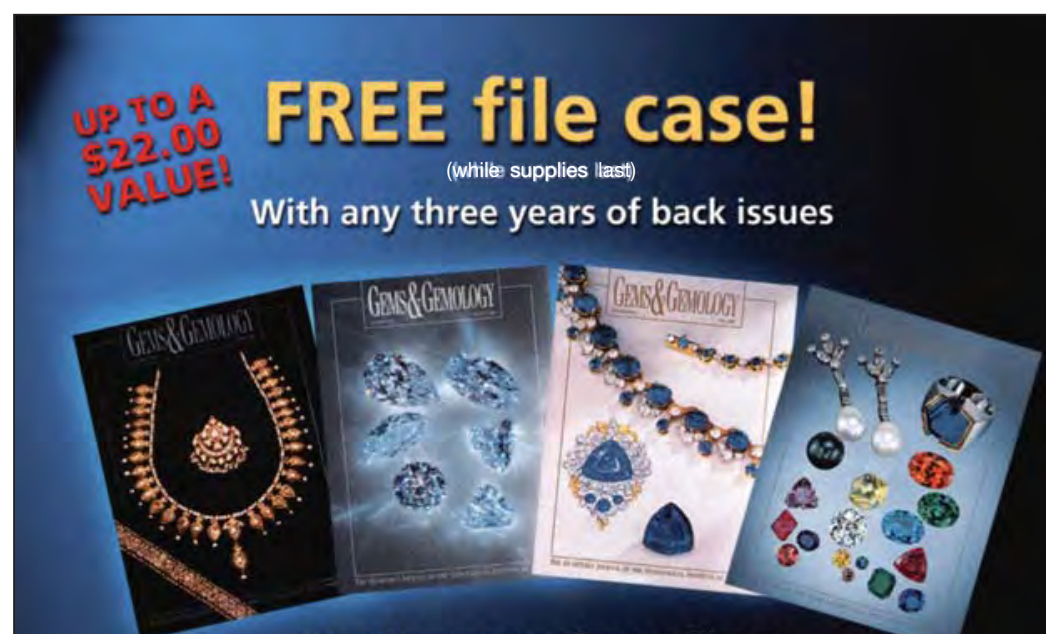

Round out your reference library with a leather-like file case embossed with the GEMS \& GEMOLOGY logo! ORDERTODAY

Call Toll Free 800-421-7250 ext. 7142 or 760-603-4000, ext. 7142 (Please see the ad in this issue for a list of topics covered in specific back issues, and please mention this ad when ordering)
There's nothing like having what you need, when you need it. That's why no gemological reference library is complete without Gems \& Gemology. In addition to in-depth research and gem locality articles, every beautifully illustrated issue features unique sections like Lab Notes and Gem News. Taken together, they provide a depth and breadth of gemological information you simply cannot find anywhere else. Take advantage of this special offer and complete your back issues today!

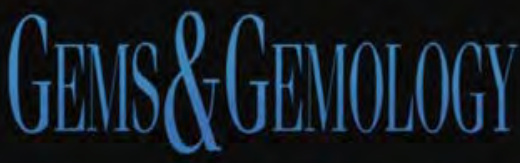

A wealth of information at your fingertips. 